\title{
Hubungan Antara Acanthosis Nigricans dengan Riwayat Keluarga Diabetes Melitus Tipe 2 pada Anak-Anak Overweight dan Obes
}

\author{
Vivekenanda Pateda, Adrian Umboh, Kristellina Tirtamulia, Frecillia Regina \\ Bagian Ilmu Kesehatan Anak, Fakultas Kedokteran Universitas Sam Ratulangi/RSUP Prof. Dr. R.D. \\ Kandou, Manado, Indonesia
}

\begin{abstract}
Latar belakang. Angka kejadian diabetes mellitus tipe-2 (DMT2) pada anak di beberapa tahun terakhir ini semakin meningkat seiring dengan meningkatnya angka kejadian obesitas pada anak. Acanthosis nigricans $(A N)$ diyakini merupakan prediktor yang baik untuk mengetahui adanya hiperinsulinemia, yang merupakan prekursor dari DMT2. Penelitian terdahulu menunjukkan prevalensi AN lebih tinggi pada anak-anak yang overweight, obes, dan mereka yang memiliki riwayat keluarga DMT2.

Tujuan. Menilai hubungan AN dengan riwayat keluarga dengan DMT2 pada anak overweight dan obes.

Metode. Penelitian cross sectional pada anak sekolah menengah pertama di kecamatan Wenang. Dilakukan pemeriksaan fisik terhadap AN dan pengisian kuesioner berisi riwayat keluarga dengan DM tipe 2 pada 102 pelajar yang overweight dan obes. Data kemudian dianalisis menggunakan uji $\mathrm{X}^{2}$.

Hasil. Didapatkan AN lebih banyak dijumpai pada anak obes (69,2\%) dibandingkan overweight (44\%). Riwayat keluarga dengan DM tipe 2 ditemukan pada 30,6\% anak obes dengan AN dan 31,8\% pada anak dengan overweight. Secara statistik perbedaan kedua prevalens tersebut di atas tidak bermakna.

Kesimpulan. Tidak terdapat hubungan yang signifikan antara acanthosis nigricans dengan riwayat keluarga diabetes melitus tipe 2 pada anak-anak overweight dan obes. (Sari Pediatri 2010;12(1):63-66).
\end{abstract}

Kata kunci: acanthosis nigricans, overweight, obes, diabetes melitus tipe 2

1 ngka kejadian diabetes mellitus tipe-2 (DMT2) pada anak di beberapa tahun terakhir ini semakin meningkat seiring dengan meningkatnya angka kejadian obesitas pada anak. Meningkatnya angka kejadian obesitas sejalan dengan perubahan gaya hidup yang

Alamat korespondensi:

Dr. Vivekenanda Pateda, Sp.A. Bagian Ilmu Kesehatan Anak FK. Unsrat/ RSU. Prof. Dr. R.D. Kandou, Manado E-mail: vivepateda@yahoo.co.id menyebabkan meningkatnya konsumsi makanan tinggi karbohidrat dan lemak, serta berkurangnya aktivitas fisik akibat perkembangan teknologi yang menyediakan berbagai macam permainan anak yang kurang menuntut aktivitas fisik anak. Prevalensi DM tipe 2 pada anak juga meningkat seiring dengan meningkatnya faktor risiko lain seperti pubertas, resistensi insulin dan riwayat keluarga dengan DM tipe $2 .^{1}$

Acanthosis Nigricans (AN) adalah penebalan dan hiperpigmentasi dari kulit yang biasanya terdapat pada 
daerah leher, ketiak, lipat paha, dan daerah fleksura lainnya. ${ }^{2,3}$ Beberapa penelitian telah menghubungkan resistensi insulin dengan acanthosis nigricans pada anak obes. ${ }^{4,5}$ Pada kulit, resistensi insulin dengan kadar insulin yang tinggi mengaktivasi fibroblas (sel dermal) dan keratinosit (sel epidermal) melalui reseptor IGF-1 sehingga menginduksi sintesis DNA, pertumbuhan sel baru dan hyperplasia, terjadi papilomatosis, hiperkeratosis dan acanthosis karena proliferasi keratinosit. ${ }^{6}$ Acanthosis nigricans diyakini merupakan prediktor yang baik untuk mengethui adanya hiperinsulinemia, yang merupakan prekursor dari DMT2. ${ }^{3}$ Acanthosis nigricans merupakan manifestasi klinis dari hiperinsulinemia pada kulit, maka AN dapat digunakan sebagai alat skrining yang sederhana, mudah, murah, dan non-invasif untuk mendeteksi kerentanan anak dan atau remaja untuk menderita DMT2 di kemudian hari. ${ }^{7,8}$ Penelitian terdahulu (Wong dkk, 2003) menunjukkan prevalensi AN lebih tinggi pada anak-anak yang overweight dan obese dan pada mereka yang memiliki riwayat keluarga dengan diabetes mellitus. ${ }^{9}$

Penelitian bertujuan melihat adakah hubungan AN dengan riwayat keluarga DM tipe 2 pada anak overweight dan obes.

\section{Metode}

Penelitian cross sectional telah dilakukan pada anak-anak sekolah menengah pertama di kecamatan Wenang. Dilakukan pengukuran berat badan (BB), tinggi badan
(TB), indeks massa tubuh (IMT) pada 102 pelajar yang dibagi dalam dua kelompok, yaitu 50 anak kelompok dengan IMT pada persentil 85-95 (Overweight) dan kelompok dengan IMT lebih besar dari persentil 95 (obes) 52 anak. Dilakukan pemeriksaan fisik dan pengisian kuesioner berisi riwayat keluarga dengan DM tipe 2. Data kemudian dianalisis menggunakan uji $\mathrm{X}^{2}$.

\section{Hasil}

Tabel 1 memperlihatkan AN lebih banyak dijumpai pada anak obes yaitu 69,2\% atau 36 dari 52 pelajar, sedangkan pada kelompok overweight ditemukan $44 \%$ atau 22 dari 50 pelajar. Hasil uji X² menyatakan kejadian AN secara bermakna lebih banyak dijumpai pada anak obes $(\mathrm{p}=0,01)$.

Tabel 2 memperlihatkan perbandingan AN dengan riwayat keluarga dengan DM tipe 2 pada anak overweight dan obes Riwayat keluarga dengan DM tipe 2 ditemukan pada 11 anak dari 36 anak obes dengan AN (30,6\%), sedangkan pada kelompok overweight ditemukan 7 dari 22 anak $(31,8 \%)$. Hasil uji $\mathrm{X}^{2}$ menyatakan riwayat keluarga DM tipe 2 tidak berbeda bermakna antara kedua kelompok $(\mathrm{p}=0,92)$.

\section{Diskusi}

Acanthosis nigricans berasal dari kata-kata dalam bahasa latin, acanthosis berarti tebal dan nigricans berarti

Tabel 1. Perbandingan antara proporsi acanthosis nigricans pada anak overweight dan obes

\begin{tabular}{|c|c|c|c|c|c|c|c|}
\hline \multirow{3}{*}{ Kelompok } & \multicolumn{4}{|c|}{ Acanthosis nigricans } & & & \multirow{3}{*}{$\mathrm{x} 2$} \\
\hline & \multicolumn{2}{|c|}{ Ada } & \multicolumn{2}{|c|}{ Tidak ada } & \multicolumn{2}{|c|}{ Total } & \\
\hline & Jumlah & $\% *$ & Jumlah & $\% *$ & Jumlah & $\% * *$ & \\
\hline Overweight & 22 & 44,0 & 28 & 56,0 & 50 & 49,0 & 6,615 \\
\hline Obes & 36 & 69,2 & 16 & 30,8 & 52 & 51,0 & $(\mathrm{p}=0,01)$ \\
\hline Total & 58 & 56,9 & 44 & 43,1 & 102 & 100 & \\
\hline
\end{tabular}

* persentase menurut baris ** persentase menurut kolom

Tabel 2. Perbandingan AN dengan riwayat keluarga DMT2 pada anak overweight dan obes

\begin{tabular}{|c|c|c|c|c|c|c|c|}
\hline \multirow{3}{*}{ Kelompok } & \multicolumn{4}{|c|}{ Riwayat keluarga DM tipe 2} & & & \multirow{3}{*}{$\mathrm{x} 2$} \\
\hline & \multicolumn{2}{|c|}{ Ada } & \multicolumn{2}{|c|}{ Tidak ada } & \multicolumn{2}{|c|}{ Total } & \\
\hline & Jumlah & $\% *$ & Jumlah & \%* & Jumlah & $\%^{* *}$ & \\
\hline Overweight & 7 & 31,8 & 15 & 68,2 & 22 & 37,9 & 0,01 \\
\hline Obes & 11 & 30,6 & 25 & 69,4 & 36 & 62,1 & $(p=0,92)$ \\
\hline Total & 18 & 31,0 & 40 & 69,0 & 58 & 100 & \\
\hline
\end{tabular}

* persentase menurut baris ${ }^{* *}$ persentase menurut kolom 
berwarna gelap. Secara klinis AN adalah kelainan kulit yang simetris, berupa penebalan kulit, berwarna kehitaman dengan permukaan yang seperti beludru. Acanthosis nigricans ditemukan pada sekitar $7 \%$ anak dan biasanya berhubungan dengan obesitas, angka kejadian meningkat sesuai usia, terutama setelah usia 10 tahun. ${ }^{5,10}$ Penelitian kami mengambil subjek dari pelajar sekolah menengah pertama karena ditemukan tingginya prevalensi AN pada remaja.

Prevalensi AN pada pasien DMT2 usia anak dan remaja sangat tinggi, hingga sekitar $90 \%$ dari seluruh pasien DMT2 pada anak dan remaja. ${ }^{10}$ Pada pasien yang menderita AN didapatkan sekitar 24\% dari seluruh pasien mengalami intolerasi glukosa, ${ }^{11}$ didukung oleh penelitian yang dilakukan oleh Smith $\mathrm{dkk}^{12}$ yang melaporkan prevalensi AN pada anak dan remaja yang memiliki faktor risiko DMT2 $25 \%$. Kobaissi $\mathrm{dkk}^{13}$ dalam penelitiannya pada anak Hispanik obes dengan risiko DM tipe-2 menunjukkan bahwa AN berhubungan dengan pengukuran langsung resistensi insulin. Penelitian di Cina oleh $\mathrm{Fu}$ $\mathrm{dkk}^{14}$ memperlihatkan adanya hubungan antara $\mathrm{AN}$ dengan obesitas, hiperinsulinemia, resistensi insulin, dan DM tipe-2. Penelitian Liang ${ }^{15}$ di tempat yang sama memperlihatkan bahwa anak obes dengan AN memperlihatkan resistensi insulin dan disfungsi sel beta pankreas yang berlebih.

Acanthosis nigricans sangat erat hubungannya dengan resistensi insulin, yaitu keadaan resistensi jaringan terhadap insulin. Penurunan respon jaringan terhadap insulin di dalam sirkulasi merangsang produksi insulin oleh pankreas, bila pankreas masih berfungsi dengan normal, sehingga terjadi hipersekresi insulin sebagai kompensasi untuk tetap menjaga kadar glukosa dalam batas normal, yang kemudian menyebabkan terjadinya hiperinsulinemia. ${ }^{16}$ Kadar insulin tinggi mengaktivasi fibroblas (sel dermal) dan keratinosit (sel epidermal) melalui reseptor IGF-1. Reseptor IGF-1 seperti reseptor insulin, merupakan suatu reseptor tirosin kinase, diaktivasi dan difosforilasi dalam keratinosit kulit. Letak IGF-1 pada basal keratinosit dan teregulasi untuk meningkat dalam kondisi proliferatif. Aktivasi IGF-1 menyebabkan peningkatan deposit glikosaminoglikan pada kulit oleh fibroblas yang menyebabkan terjadinya proliferasi keratinosit sehingga terjadi hiperpigmentasi, hiperkeratosis, dan papilomatosis. ${ }^{6}$

Semakin tinggi IMT, makin tinggi resistensi insulin sehingga prevalensi AN makin tinggi pula.
Kami menemukan AN lebih banyak pada anak obes $(\mathrm{p}=0.01)$. Obesitas pada anak merupakan faktor risiko untuk DM tipe 2. Hiperinsulinemia banyak ditemukan pada anak dengan riwayat keluarga dengan DM tipe 2. Keadaan hiperinsulinemia merupakan predisposisi untuk AN, merupakan penanda hiperinsulinemia, akibat resistensi insulin jaringan. Sehingga AN dapat digunakan sebagai prediktor seorang anak memiliki risiko menderita DMT2 di kemudian hari. Jadi AN dapat digunakan sebagai alat skrining yang mudah, murah, dan non-invasif untuk mendeteksi dini DMT2 pada anak dan remaja. ${ }^{17}$

Uji saring AN dapat dilanjutkan untuk menyaring DMT2 pada anak, karena dengan uji saring terhadap AN saja tidak memberikan informasi tentang apa yang harus dilakukan setelah diketahui seorang anak atau remaja menderita AN. Oleh karena itu dibuat suatu uji saring berupa skema yang menunjukkan langkah-langkah berikutnya yang perlu dilakukan bila didapatkan adanya AN. Langkah-langkah yang perlu dilakukan apabila didapatkan adanya AN adalah mengukur BB dan TB, menilai IMT dan pemeriksaan kadar gula darah apabila ditemukan kelainan pada BB dan IMT. Protokol skrining DM tipe 2 adalah, ${ }^{18}$ usia $\geq 10$ tahun, IMT >Persentil 95, acanthosis nigricans, dan riwayat keluarga dengan DM tipe 2

Penelitian kami merupakan studi pendahuluan hubungan AN dengan resistensi insulin (sindrom metabolik), bertujuan mempelajari hubungan antara salah satu faktor risiko DM tipe 2 yaitu riwayat keluarga DM tipe 2 dengan kejadian AN pada anak overweight dan obes. Banyak penelitian sebelumnya (Stoddart dkk, ${ }^{19}$ Kong ${ }^{20}$ ) memperlihatkan ditemukannya persentase riwayat keluarga dengan DM tipe 2 pada anak dengan AN lebih besar dua kali lipat daripada tanpa AN. Namun hal ini tidak ditemukan pada penelitian kami. Prevalensi AN dihubungkan dengan tinggi riwayat keluarga dengan DM tipe 2 ternyata tidak signifikan, disebabkan resistensi insulin disebabkan pula oleh faktor lain, seperti perubahan gaya hidup yang menyebabkan DM tipe 2, dan etiologi lain. Kekurangan studi ini adalah jumlah subjek yang terbatas, kuesioner yang kurang relevan, serta tidak memakai pengambilan sampel darah untuk diabetes, sehingga tidak dapat mengidentifikasi orang tua yang belum terdiagnosis DM tipe 2 .

Perlu diadakan penelitian lebih luas dengan jumlah sampel lebih besar serta pemakaian kuesioner yang lebih relevan sehingga mengurangi false negative 
penilaian riwayat keluarga DM tipe 2. Kesimpulan, tidak terdapat hubungan antara acanthosis nigricans dengan riwayat keluarga diabetes melitus tipe 2 pada anak-anak overweight dan obes.

\section{Daftar Pustaka}

1. Sahay BK, Sahay RK. Type 2 diabetes in the young. Int J Diab Dev Ctries 2003;23:51-4.

2. Lucky AW, Powell J. Cutaneus manifestation of endocrine metabolic and nutritional disorders.in pediatric dermatology. Edisi ke-3. New York: Mosby; 2003.h.915-6.

3. Hogan PA, Harper J, Oranje A, Prose N. Cutaneus manifestation of endocrine disease in textbook of pediatric dermatology. Australia. 2006.h.2007-8.

4. Morelli JG. Diseases of the epidermis. Dalam: Kliegman RM, Behrman RE, Jenson HB, Stanton BF, penyunting. Nelson textbook of pediatrics. Edisi ke-18. Philadelphia: WB Saunders; 2007.h.2708-14.

5. Wolff C, Hoang S, Flannery D, Wermuth L. A preliminary study of diet, overweight, elevated blood pressure, and acanthosis nigricans among K-9th grade native American students. Californian J Health Promotion 2006; 4:77-87.

6. Grandhe NP, Bhansali A, Dofra S, Kumar B. Acanthosis nigricans: relation with type 2 diabetes mellitus, anthropometric variables, and body mass in Indians. Postgrad Med J 2005;81:541-51.

7. Garofalo L., Biscozzi A.M., Mastrandrea V, Bonifazi E. Pediatric Dermatology Unit, University of Bari, Bari (Italy) acanthosis nigricans vulgaris. a marker of hyperinsulinemia, Eur J Pediat. Dermatol 2003;13: 85-8.

8. Hardin DS. Screening for type 2 diabetes in children with acanthosis nigricans. The Diabetes Educator 2006; 32: 54-7.

9. Wong W, Hollier DR, Myres D, Fraley JK, Smith B, Klish W. Prevalence of acanthosis nigricans in a multiethnic pediatric population. Journal of Children's Health 2003;3:323-31.

10. Skelton JA, Rudolph CD. Overweight and obesity.
Dalam: Kliegman RM, Behrman RE, Jenson HB, Stanton BF, penyunting. Nelson Textbook of pediatrics. Edisi ke-18. Philadelphia: WB Saunders;2007.h.23242.

11. Brickman WJ, Howard JC, Metzger BE. Abnormal glucose tolerance in children with acanthosis nigricans: a chart review. Diabetes 2002; 51: A429.

12. Smith WG, Gowanlock W, Babcock K. Prevalence of acanthosis nigricans in first nations children in Central Ontario, Canada. Canadian Journal Of Diabetes 2004:28:410-4.

13. Kobaissi HA, Weigensberg MJ, Ball GDC, Cruz ML, Shaibi GQ, Goran MI. Relation between acanthosis nigricans and insulin sensitivity in overweight hispanic children at risk for type 2 diabetes. Diabetes Care 2004;27:1412-6.

14. Fu JF, Liang L, Dong GP, Jiang YJ, Zou CC. Obese children with benign acanthosis nigricans and insulin resistance: analysis of 19 cases. Zhonghua Er Ke Za Zhi 2004;42:917-9.

15. Liang XJ, Zhu C, Yan C. Clinical significance of pancreatric beta-cell function in obese children with acanthosis nigricans. Zhonghua Er Ke Za Zhi 2004; $42: 405-7$.

16. Gungor, Hannon T, Libman I. Type 2 Diabetes mellitus in youth: the complete picture to date. Pediatr Clin N Am 2005;52:1579-61.

17. Anand SG, Mehta SD, Adams WG. Diabetes mellitus screening in pediatric primary care. Pediatrics 2006; 118: 1888-95.

18. Hardin DS. Screening for type 2 diabetes in children with acanthosis nigricans. The diabetes Educator 2006;32:547-52.

19. Stoddart ML, Blevins KS, Lee ET, Wang W, Blackett PR. Association of acanthosis nigricans with hyperinsulinemia compared with other selected risk factors for type 2 diabetes in Cherokee Indians. The Cherokee Diabetes Study. Diabetes Care 2002;25:1009-14.

20. Kong AS, Williams RL, Smith M. Acanthosis nigricans and diabetes risk factors: prevalence in young persons seen in Southwestern US Primary Care Practices. Ann Fam Med 2007;5:202-8. 